\title{
ALEXANDR PUSHKIN
}

\section{Recuerdo}

Cuando cesa el estrépito del día en torno al hombre, y a las mudas calles del pueblo, clarísima, desciende la sombra de la noche; cuando el sueño premia el trabajo;

entonces vivo horas amargas de vigilia que se consumen en silencio.

En la nocturna paz, en mi interior se agita intima sierpe de la culpa;

y los sueños rebullen; y a la mente abatida por la pena viene el dolor.

Ante mi, lentamente, la callada memoria desplïega su largo pergamino;

y al leer en él con asco aquello que yo he sido, maldigo todo y me estremezco y amargamente lloro y amargamente gimo, mas no borro las tristes líneas.

Traducción de Selma Ancira y Gerardo Torres 